\title{
Weed control efficiency and weed index as influenced by weed management practices in machine transplanted rice (Oryza sativa L.)
}

\author{
R. B. Negalur ${ }^{1 *}$ and A. S. Halepyati ${ }^{2}$ \\ Agricultural Research Station, Gangavati, University of Agricultural Sciences, Raichur-583227 (Karnataka), INDIA \\ *Corresponding author. E-mail: tushberkipilli@rediffmail.com
}

Received: January 27, 2016; Revised received: July 20, 2016; Accepted: October 31, 2016

\begin{abstract}
Field experiment on effect of different weed management practices in machine transplanted rice (Oryza sativa L.) was conducted at ARS, Gangavathi, University of Agricultural Sciences, Raichur, Karnataka during kharif, 2012 and 2013 under irrigated condition in clay soil. Pooled mean indicated that, application of butachlor $50 \mathrm{EC} \mathrm{fb}$ passing of power operated low land rice weeder twice at 20 and 30 DAT with hand weeding in intra row space recorded significantly lower grassy weed population and dry weight at 40, 60 DAT and at harvest $(1.98,2.47,2.97 /$ $0.25 \mathrm{~m}^{2}$ and $1.00,1.20,1.47 \mathrm{~g} / 0.25 \mathrm{~m}^{2}$, respectively), sedge weed population and dry weight $(2.61,3.21,3.52 /$ $0.25 \mathrm{~m}^{2}$ and $1.19,1.48,1.71 \mathrm{~g} / 0.25 \mathrm{~m}^{2}$, respectively) and broad leaved weed population and dry weight (1.68, $2.10,2.52 / 0.25 \mathrm{~m}^{2}$ and $0.91,1.06,1.28 \mathrm{~g} / 0.25 \mathrm{~m}^{2}$, respectively). Significantly higher WCE (87.53\%), lower weed index $(3.11 \%)$, grain and straw yield $\left(5160\right.$ and $6482 \mathrm{~kg} \mathrm{ha}^{-1}$, respectively), gross and net returns (Rs. 92,212 and $50,410 \mathrm{ha}^{-1}$, respectively), and B:C of 2.22 over unweeded check. Hence, application of butachlor 50 EC fb passing of power operated low land rice weeder at 20 and 30 DAT with hand weeding in intra row space was found to be the best weed control method as it recorded higher B:C. Present conventional manual weeding is which is not advantageous as it is costlier, time consuming and labour may trample and damage rice seedlings. Mechanical weeder and sequential application can overcome the same.
\end{abstract}

Keywords: Conoweeder, Hand weeding, Low land power operated paddy weeder, Post emergent, Pre-emergent

\section{INTRODUCTION}

Rice (Oryza sativa L.) is cultivated in command areas of Cauvery basin in South, Tungabhadra and Upper Krishna commands in North where manual transplanting is the major method of planting. In Northern Karnataka that too in Hyderabad - Karnataka region, major paddy area is concentrated in Koppal, Raichur, Yadgir and Bellary districts. The area under rice in Karnataka is $1.33 \mathrm{~m}$ ha with an annual production of 3.76 million tonnes and with a productivity of $2828 \mathrm{~kg}$ per ha (Anonymous, 2014).

Rapid deprivation of available nutrients leads to faster growth of weeds than the rice crop. Hence, weed management during the early period of rice is one of the most critical factors for successful production of rice. Present conventional method of manual weeding is effective method of weed control. However, it is not advantageous as it is costlier, time consuming. Manually it is difficult to differentiate and remove the grassy weeds. In such a situation, the chemical weed control becomes an alternative method for weed control. Preferably, the application of pre-emergent chemical herbicide is a vital tool for effective and cost efficient weed control in rice, which encounters weed competition from the day of germination. Adjusting the time of application, reducing the dose of the herbicide or use of herbicides in sequence can improve selectivity and adequate weed control in trans
(Mallikarjun et al., 2014). Various Universities in India showed that by using manually operated cono weeder reduced drudgery due to less time taken (50-55\%) compared to hand weeding. The use of equipment also resulted in saving of cost of operation by 45 per cent. Farmers are of the opinion that cono weeder operation in standing position of operator allowed weeding without fatigue (Dixit and Khan, 2009). Pasha et al. (2012) reported that weed density and weed dry matter at flowering stage were significantly lower under integrated weed management practice of butachlor @ $1.5 \mathrm{~kg} \mathrm{ha}^{-1}$ combined with cono weeding thrice at 15 days interval and hand weeding at 20 and 40 days after planting. The present investigation was carried out to study the weed control efficiency and weed index as influenced by weed management practices in machine transplanted rice (Oryza sativa L.).

\section{MATERIALS AND METHODS}

A field experiment was conducted at Agricultural Research Station, Gangavathi, University of Agricultural Sciences, Raichur, Karnataka, during kharif, 2012 and 2013. The experiment was laid in strip-plot design. The soil of the experimental site was medium deep black clay with soil reaction (8.2), electrical conductivity (2.1) determined following the procedure given by Jackson (1973), available N (247.2 $\left.\mathrm{kg} \mathrm{ha}^{-1}\right)$ Subbaiah and 
Asija (1956), available $\mathrm{P}_{2} \mathrm{O}_{5}\left(50.2 \mathrm{~kg} \mathrm{ha}^{-1}\right)$ Olsen et al. (1954) and available $\mathrm{K}_{2} \mathrm{O}\left(357.6 \mathrm{~kg} \mathrm{ha}^{-1}\right.$ ) Jackson (1973) at surface $0-20 \mathrm{~cm}$ soil depth.

Agricultural Research Station, Gangavathi is situated in the Northen Dry Zone of Karnataka between $15^{\circ} 15^{\prime} 40^{\prime \prime}$ North latitude and $76^{\circ} 31^{\prime} 40^{\prime \prime}$ East longitude at an altitude of $419 \mathrm{~m}$ above mean sea level and represents irrigated transplanted rice belt of Tungabhadra command area. The experiment consisted twelve different weed management practices viz., pre- emergent application of butachlor $50 \mathrm{EC}$ fb hand weeding at $30 \mathrm{DAT}\left(\mathrm{T}_{1}\right)$, Bensulfuron methyl $0.6 \%$ + Pretilachlor $6 \%$ fb hand weeding at $30 \mathrm{DAT}\left(\mathrm{T}_{2}\right)$, Butachlor $50 \mathrm{EC} \mathrm{fb}$ 2, 4-D Sodium salt $80 \mathrm{WP}$ at $25 \mathrm{DAT}\left(\mathrm{T}_{3}\right)$, Butachlor $50 \mathrm{EC}$ fb Bispyriback sodium $10 \mathrm{SC}$ at $25 \mathrm{DAT}\left(\mathrm{T}_{4}\right)$, Bensulfuron methyl $0.6 \%$ + Pretilachlor 6\% fb 2, 4 - D fb Sodium salt $80 \mathrm{WP}$ at 25 DAT $\left(\mathrm{T}_{5}\right)$, Bensulfuron methyl $0.6 \%$ + Pretilachlor $6 \% \mathrm{fb}$ Bispyriback sodium $10 \mathrm{SC} 25 \mathrm{DAT}\left(\mathrm{T}_{6}\right)$, Butachlor 50 $\mathrm{EC} \mathrm{fb}$ power operated low land rice weeder twice at 20 and 30 DAT with hand weeding in intra row space $\left(\mathrm{T}_{7}\right)$, passing of power operated low land rice weeder at 20 and 30 DAT with hand weeding in intra row space $\left(T_{8}\right)$, passing of Conoweeder twice at 10 and 20 DAT $\mathrm{fb}$ hand weeding at 30 DAT $\left(T_{9}\right)$ and two hand weedings at 20 and 40 days after transplanting $\left(\mathrm{T}_{10}\right)$ were compared with unweeded control $\left(T_{11}\right)$ and weed free check $\left(T_{12}\right)$. The land was prepared using tractor drawn cultivator twice, followed by puddling twice with disc puddler and finally leveled using tractor drawn spike tooth harrow and kept ready for planting. Weed control treatments were imposed as per the combination of pre, post emergent herbicides and use of weeders, time and dosage of the chemicals. From the day of transplanting upto 10 days, a thin film of water was maintained and thereafter $5 \mathrm{~cm}$ standing water was maintained upto 10 days before harvesting. Water was drained during fertilizer application and spraying of weedicides and chemicals. Recommended dose of fertilizers (150:75:75 and $20 \mathrm{~N}: \mathrm{P}_{2} \mathrm{O}_{5}: \mathrm{K}_{2} \mathrm{O}$ and $\mathrm{ZnSO}_{4}$ $\mathrm{kg} / \mathrm{ha}$ ) were applied as per the recommendation and time. The weed count of different weeds from 0.25 squre meter area was recorded at 20 days interval and then the weeds after washing in water were sun dried and then oven dried at $65{ }^{\circ} \mathrm{C}$ and the dry weight of weeds were recorded and expressed in grams. Both grain and straw were sun dried for a week and dry weights were recorded. For computing the cost of cultivation, different variable cost of items was considered. The cost includes expenditure on seeds, fertilizer, weedicides, irrigation, plant protection chemicals, hiring charges of transplanter, conoweeder, low land power operated paddy weeder, fuel cost and labour charges prevailed in market during 2012 and 2013.

\section{RESULTS AND DISCUSSION}

Weed population: Different weed control treatments had significant influence on weed population at all the growth stages. The study indicated that the highest weed density was rerded in unweeded control (44.15,

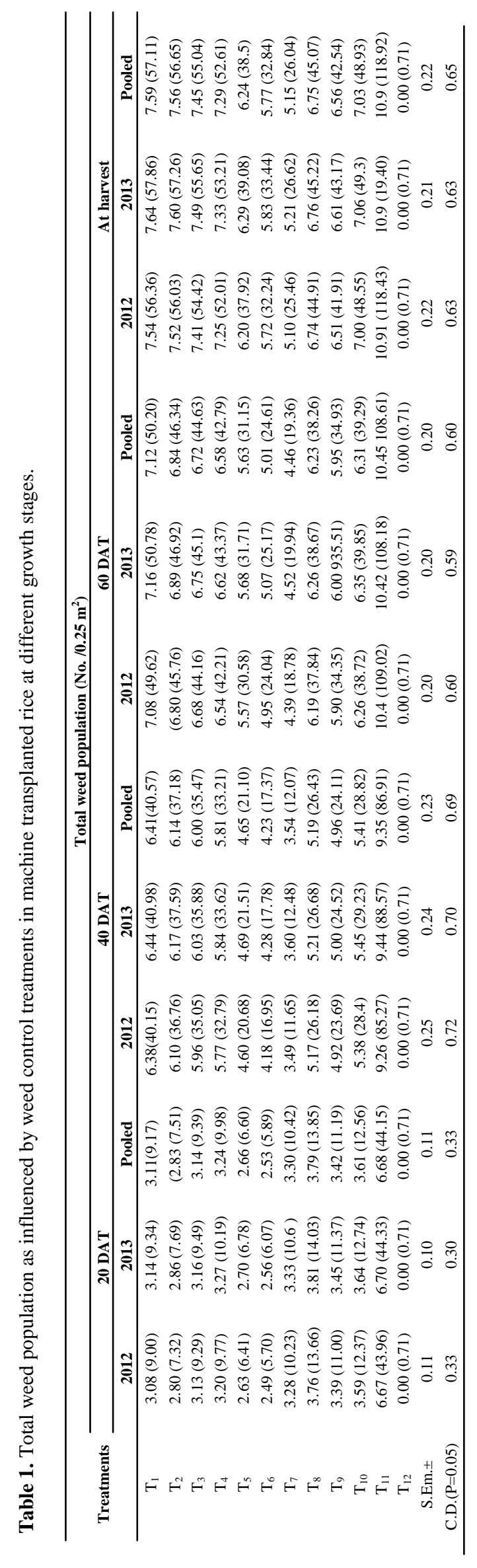


R. B. Negalur and A. S. Halepyati / J. Appl. \& Nat. Sci. 8 (4): 1947-1952 (2016)
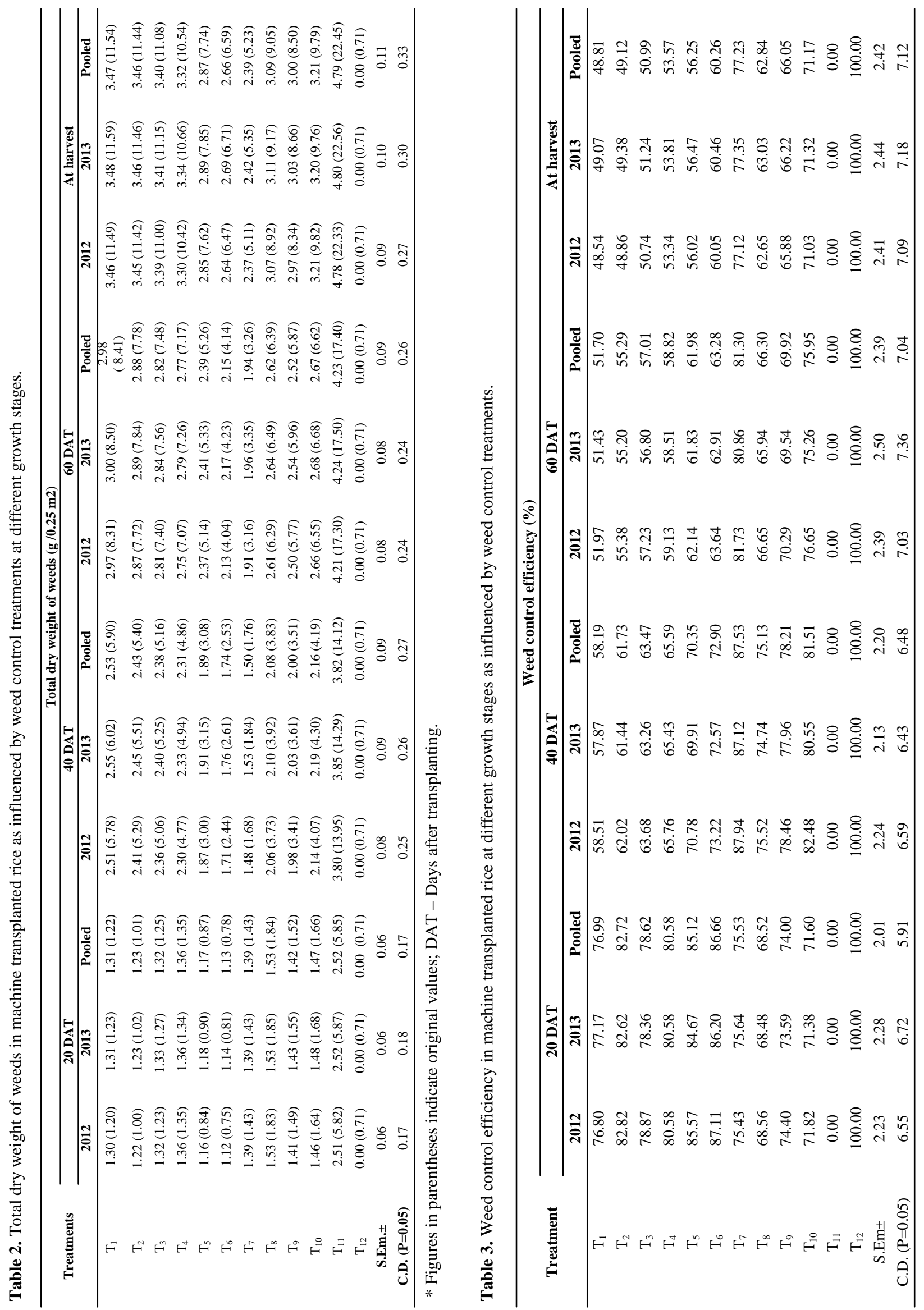


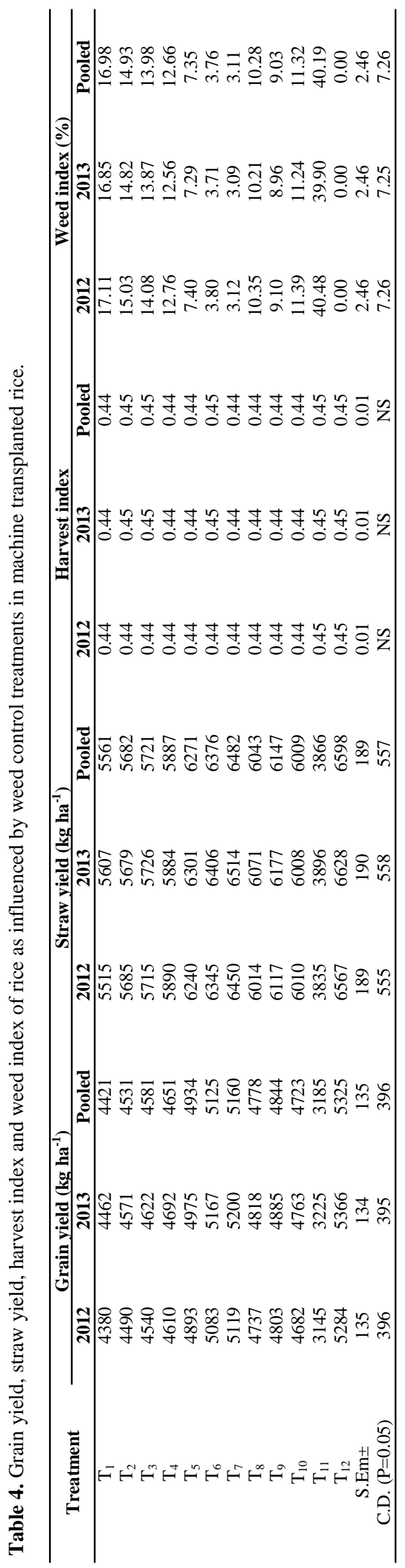

86.91, 108.61 and 118.92 at 20, 40, 60 DAT and at harvest, respectively) and lowest with weed free check $\left(0.71,0.71,0.71\right.$ and $0.71 / 0.25 \mathrm{~m}^{2}$ at $20,40,60$ DAT and at harvest). The total weed population differed significantly due to different weed control treatments at all the growth stages (Table 1). The study indicated that the highest weed density was recorded in unweeded control $(44.15,86.91,108.61$ and 118.92 at 20, 40, 60 DAT and at harvest, respectively) and lowest with weed free check $(0.71,0.71,0.71$ and $0.71 / 0.25$ $\mathrm{m}^{2}$ at 20, 40, 60 DAT and at harvest). The effect of pre - emergent herbicides was very effective at early stage and among the different weed control practices at 20 DAT, application of bensulfuron methyl $0.6 \%+$ pretilachlor $6 \%$ fb bispyribac sodium $10 \mathrm{SC}$ was very effective in controlling all types of weeds $\left(2.53 / 0.25 \mathrm{~m}^{2}\right)$ over unweeded control $\left(6.68 / 0.25 \mathrm{~m}^{2}\right)$ thus indicating the efficacy of the bensulfuron methyl $0.6 \%+$ pretilachlor $6 \%$. Herbicide application in sequence was found to be better than single application of herbicides and in combination with weeders. These results are in conformity with findings of Sanjoy Saha (2005) The reduction in the weed population and weed dry weight in these treatments was mainly due to effective control of weeds at all stages of crop growth period, Sunil et al. (2010) who reported that reduced weed dry weight in these treatments was mainly due to effective control of all monocots, dicots and sedges at early stages and as a consequence recorded lower total weed population at all growth stages., Bhanu Rekha et al. (2004) and Srivastava et al. (2008) and Application of bensulfurom-methyl and triasulfuron at lower doses was found most effective on sedges and broad-leaved weeds than grasses and constituted higher composition of grassy weeds than butachlor and pretilachlor at higher doses. This was owing to the fact that low dose herbicides when applied remained unaffected on grasses due to short life period of these herbicides as grassy weeds emerged at later stages. The greater selectivity and high bio-efficacy of weedicides in controlling weeds without causing phytotoxicity on rice plant was reported by Swapan Kumar Maity and Mukherjee (2009).

However, from 40 DAT onwards the total weed density recorded with the application of butachlor $50 \mathrm{EC}$ $\mathrm{fb}$ passing of power operated low land rice weeder twice at 20 and 30 DAT with hand weeding in intra row space $(3.54,4.46$ and 5.15 at 40,60 DAT and at harvest, respectively) was lower and it was followed by application of bensulfuron methyl $0.6 \%+$ pretilachlor $6 \% \mathrm{fb}$ bispyribac sodium $10 \mathrm{SC}(4.23,5.01$ and 5.77 at 40, 60 DAT and at harvest, respectively) and bensulfuron methyl $0.6 \%+$ pretilachlor $6 \% \mathrm{fb} 2$, 4 - D sodium salt $80 \mathrm{WP}(4.65,5.63$ and 6.24 at 40, 60 DAT and at harvest, respectively) over unweeded check $(9.35,10.45$ and 10.93 at 40,60 DAT and at harvest, respectively) indicating weed controlling efficiency of herbicides when applied in sequence. Similar 
results were also reported by Yadav et al. (2009), indicating Bispyribac@25 g/ha applied at 15 or 25 DAT was adjudged the most suitable herbicidal treatment resulting in $174-199 \%$ and $37-41 \%$ increase in the rice grain yield over weedy check during 2006 and 2007, respectively, without causing any phyto-toxicity on rice.

Weed dry weight: The dry weight of weeds also varied significantly because of various weed management practices at all the growth stages (Table 2). The lowest dry weight of weeds was noticed with the application of bensulfuron methyl $0.6 \%+$ pretilachlor $6 \%$ fb bispyribac sodium $10 \mathrm{SC}\left(1.13 / 0.25 \mathrm{~m}^{2}\right)$ as against $2.52 /$ $0.25 \mathrm{~m}^{2}$ in unweeded control at $20 \mathrm{DAT}$ and the lowest with weed free check $\left(0.71 / 0.25 \mathrm{~m}^{2}\right)$. The findings are in conformity with Srivastava et al. (2008) who attributed reason to broad spectrum properties exhibited by this herbicide.and Sunil et al. (2010). This was mainly due to better control of weeds' growth even upto harvest resulting in lower dry weight of weeds.

Among the different combinations of herbicides and weeders, application of butachlor $50 \mathrm{EC} \mathrm{fb}$ passing of power operated low land rice weeder twice at 20 and 30 DAT with hand weeding in intra row space recorded lower dry weight of weeds $\left(1.39 \mathrm{~g} / 0.25 \mathrm{~m}^{2}\right.$ at 20 DAT) over unweeded check $\left(2.52 \mathrm{~g} / 0.25 \mathrm{~m}^{2}\right)$. These results are in line with Yadav et al. (2009), Sunil et al. (2010) and Pasha et al. (2012) who reported integration of weed management practice helps in better control of weed growth, there by less competition for resources which leads to good crop growth and yield attributes than the single weed management practice The similar trend as that of weed count was followed with total dry weight of weeds. Herbicide application in sequence was found to be better than single application of herbicides and in combination with weeders. Application of butachlor $50 \mathrm{EC}$ fb passing of power operated low land rice weeder twice at 20 and 30 DAT with hand weeding in intra row space recorded lower total dry weight of weeds $(1.50,1.94$ and $2.39 \mathrm{~g} / 0.25$ $\mathrm{m}^{2}$, respectively) compared to unweeded control (3.82, 4.23 and $4.79 \mathrm{~g} / 0.25 \mathrm{~m}^{2}$, respectively). The next best treatments with respect to total dry weight of weeds were application of bensulfuron methyl $0.6 \%+$ pretilachlor $6 \%$ fb bispyribac sodium 10 SC $(1.74,2.15$ and 2.66 at 40,60 DAT and at harvest, respectively) and bensulfuron methyl $0.6 \%$ + pretilachlor $6 \%$ fb $2,4-\mathrm{D}$ sodium salt $80 \mathrm{WP}(1.89,2.39$ and 2.87 at 40,60 DAT and at harvest, respectively). Similar results were reported by Bhanu Rekha et al. (2004), Walia et al. (2008), Bajpai and Singh (1992), Maity and Mukherjee (2009) who reported that selectivity and higher bio -efficacy of both bensulfuron methyl $0.6 \%+$ pretilachlor $6 \%$ and bispyribac sodium $10 \mathrm{SC}$ in controlling weeds without causing phytotoxicity on rice plant.

Weed control efficiency: The crop performance in terms of growth and yield has direct relationship with the weed control efficiency and oppositely related to the weed index. Weed free check recorded maximum and unweeded control showed the minimum weed control efficiency at all the growth stages (Table 3). Pooled data states that application of bensulfuron methyl $0.6 \%$ + pretilachlor $6 \%$ fb bispyribac sodium 10 SC recorded higher weed control efficiency $(86.66 \%)$ at 20 DAT, whereas application of butachlor $50 \mathrm{EC} \mathrm{fb}$ passing of power operated low land rice weeder twice at 20 and 30 DATwith hand weeding in intra row space showed higher weed control efficiency (87.53, 81.30 and $77.23 \%$, respectively at 40, 60 DAT and at harvest, respectively) highlighting the combined effect of weedicides, power operated weeder and hand weeding in intra row spaces. Sequential application of bensulfuron methyl $0.6 \%$ + pretilachlor $6 \%$ fb bispyribac sodium $10 \mathrm{SC}$ was the next best treatment recording higher weed control efficiency indicating that the effect of sequential application of bispyribac sodium as post emergent helped in maintaining higher weed control efficiency till the harvest.

Weed index: Weed index is the measure of yield reduction due to weed competition. The unweeded check recorded the highest weed index $(40.19 \%)$ due to severe crop weed competition and the lowest weed index was observed with weed free check $(0.00 \%)$. Among the different weed management treatments the lower weed index values were noticed with the application of butachlor $50 \mathrm{EC}$ fb passing of power operated low land rice weeder twice at 20 and 30 DAT with hand weeding in intra row space $(3.11 \%)$ which was found to be on par with the application bensulfuron methyl $0.6 \%$ + pretilachlor $6 \%$ fb bispyribac sodium 10 SC $(3.76 \%)$ and bensulfuron methyl $0.6 \%+$ pretilachlor $6 \%$ fb 2,4 -D sodium salt $80 \mathrm{WP}(7.35 \%)$ indicating the efficiency of these herbicides in sequence and combination of weeders and hand weeding. Similar reports were also made by Satyanarayana et al. (1997), Swapan Kumar Maity and Mukherjee (2009) where in the highest value of weed control efficiency and lowest value of weed index were recorded with the butachlor + brown manuring treatment reflecting its selectivity and higher bio-efficacy in controlling weeds without causing any phytotoxicity on rice plant.

Yield: Significantly higher grain yield $\left(5160 \mathrm{~kg} \mathrm{ha}^{-1}\right)$ and straw yield $\left(6482 \mathrm{~kg} \mathrm{ha}^{-1}\right)$ over unweeded control were recorded with the application of butachlor 50 EC $\mathrm{fb}$ passing of power operated low land rice weeder twice at 20 and 30 DAT with hand weeding in intra row space, but was found to be on par with application of bensulfuron methyl $0.6 \%$ + pretilachlor $6 \%$ fb bispyriback sodium $10 \mathrm{SC}$ and bensulfuron methyl $0.6 \%$ + pretilachlor $6 \% \mathrm{fb} 2,4$ - D sodium salt $80 \mathrm{WP}$ (Table 4). This work is in conformity with the work of Bhat et al. (2008) and Sunil et al. (2010) who recorded such increased dry matter production in rice grown under wet land condition and attributed the differences 
due to better growth of plants on account of reduced weed competition at critical crop growth stages, resulting in increased availability of nutrients, space and light. Similar results were also reported by Sathyanarayana et al. (1997), Behera and Jena (1998) and Walia et al. (2008). Who attributed increased yield on account of higher yield components like productive tillers per hill, panicle length, weight of panicle, filled spikelets per panicle and lower sterility per cent and 1000-grain weight.

As it is a new avenue for weed management especially in machine transplanted rice, the study was aimed at integrated approach and all the chemicals that were found effective in normal transplanting method were also found effective in the present study also. However a very rare experiments on paddy weeder (Low land power operated paddy weeder) alone or in combination with Weedicides were conducted by other researchers., In the present study combination of pre-emergrnt herbicide and weeder was found to most effective in controlling weeds.

\section{Conclusion}

The study thus indicated that, the treatment receiving pre emergent herbicide butachlor 50 EC @ 2.5 lit ha $^{-1}$ $\mathrm{fb}$ passing of power operated low land rice weeder twice at 20 and 30 DAT with hand weeding in intra row space was found to be most effective and economical, as evidenced by recording significantly lower weed population, weed dry weight, weed index $(3.11 \%)$, higher weed control efficiency at 40 DAT (87.53), grain and straw yield (5160 and $6482 \mathrm{~kg} \mathrm{ha}^{-1}$, respectively).

\section{REFERENCES}

Anonymous. (2014). The Hindu Survey of Indian Agric., pp. 43-46

Bajpai, R.P. and Singh, V.K. (1992). Effect of butachlor application on sprouted direct seeded rice in puddled field. Indian J. Agron, 37(1): 171-173

Behera, A.K. and Jena, S.N. (1998). Weed control in direct seeded rainfed upland rice. Indian J. Agron, 43(2): 284-290

Bhanu Rekha, K., Kavitha, P. and Srinivasa Raju, M. (2004). Performance of herbicides for weed control in transplanted rice (Oryza sativa L.). Andhra Agric. J., 51(1 \& 2): $1-4$

Bhat, I.A., Dileep Kachroo. and Manzoor Ahmad Ganai.
(2008). Efficiency of different herbicides on growth and yield of direct wet seeded rice sown through drum seeder. Crop Res., 36(1, 2 \& 3): 33-36

Dixit, A. and Khan, J. N. (2009). Improved cost effective implements for small rice farmers. Agricultural Mechanization in Asia, Africa and Latin America, 40 (2): $30-35$

Jackson, M.L. (1973). Soil Chemical Analysis, (Ed.). Prentice-Hall of India, Pvt. Ltd., New Delhi, pp. 121125

Mallikarjun, A.S., Channabasavanna, Sudheendrasaunshi. and Shrinivas, C.S. (2014). Effect of herbicides on weed control and yield of wetSeeded rice (Oryza sativa L.). The Bioscan, 9(2): 581-583

Olsen, S.R., Cole, C.L., Watanabe, F.S. and Deaw, D.A. (1954). Estimation of available phosphorous in soils by extraction with sodium bicarbonate. United States Departments of Agriculture Circular, p.939

Pasha, L.M., Krishna, L., Bhadru, D. and Naik, R.B.M. (2012). Comparative performance of different weed management practices in system of rice intensification. Madras Agric. J., 99(7-9):473-475

Sanjoy Saha. (2005). Evaluation of some new herbicide formulations alone or in tank mixture in transplanted rice. Indian J. Weed Sci., 37(1 \& 2): 125-128

Sathyanarayana, V., Latchanna, A. and Varaprasad, P.V. (1997). Weed management in direct seeded upland paddy. Ann. Agric. Res., 18(3): 385-387

Srivastava, V.K., Krishan Mohan, T., Singh, R.P. and Singh, R.N. (2008). Bio-efficacy of sulfonylurea herbicides in transplanted ric (Oryza sativa L.). Indian J. Weed Sci., 40 (3\&4):193-195

Subbaiah, B.V. and Asija, G.L. (1956). Rapid procedure for determination of available nitrogen in soils. Current. Sci., 31: 196

Sunil, C.M., Shekara, B.G., Kalyanamurthy, K.N. and Shankara Lingappa. (2010). Growth and yield of aerobic rice as influenced by integrated weed management practices. Indian J. Weed Sci., 42(3 \& 4): 180-183

Swapan Kumar Maity and Mukherjee, P.K. (2009). Integrated weed management in dry direct seeded summer rice. Indian J. Agric. Sci., 79(12): 28-31

Walia, U.S., Bhullar, M.S., Shelly Nayyar and Walia, S.S. (2008). Control of complex weed flora of dry-seeded rice with pre-and post-emergence herbicides. Indian $J$. Weed Sci., 40 (3\&4): 161-164

Yadav, D.B., Ashok Yadav and Punia, S.S. (2009). Evaluation of bispyribac-sodium for weed Control in transplanted rice. Indian J. Weed Sci., 41(1 \& 2): 23-27 